http://heanoti.com/index.php/hn

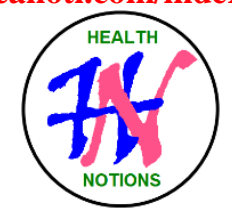

RESEARCH ARTICLE

URL of this article: http://heanoti.com/index.php/hn/article/view/hn30112

\title{
Evaluation of DHF Surveillance Based on Attributes in Pasuruan District
}

\author{
Ahmad Zamzam Hariro ${ }^{1(\mathrm{CA})}$, Chatarina Umbul Wahyuni' ${ }^{2}$, Supa'at Setia Hadi ${ }^{3}$ \\ ${ }^{1}$ Department of Epidemiology, Faculty of Public Health, Airlangga University, Indonesia; a.hariro@yahoo.com \\ (Corresponding Author) \\ ${ }^{2}$ Department of Epidemiology, Faculty of Public Health, Airlangga University, Indonesia; \\ chatrin03@yahoo.com \\ ${ }^{3}$ Health Office of Sidoarjo District, Indonesia; supaatsetiahadi@yahoo.com
}

\begin{abstract}
Dengue Hemorrhagic Fever (DHF) is one of health problems in Pasuruan that the number of sufferers was increase. Those problems would not actually happen if the surveillance gose well. The purpose of this study was to describe the problem of DHF surveillance based on attributes as well as provide an alternative solution. This research was a descriptive study with evaluation study design. This study was conducted in 16 Public Health Centers and health office of Pasuruan District. Data were collected through interviews with DHF officers in 16 PHC and health office of Pasuruan District, using questionnaires, and document analysis against DHF data reports. The problems was not simple in feedback, not acceptable in feedback, and not on time in feedback because the feedback only give every 3 months. Data was not representative because data can't describe population based on time and place. Data was unstable because there were $41.25 \%$ respondent that loss of data. Provide personal computers for program officers is needed to keep the data from lost and always available. Motivate the public health centers to form an independent jumantik cadre with funding sources from public health center or sub district for optimal PSN and data reports.
\end{abstract}

Keywords: DHF, Surveillance, Attributes

\section{INTRODUCTION}

\section{Background}

Dengue Hemorrhagic Fever (DHF) is one of the world's health problems that the number of sufferers is increase. DHF is an infectious disease caused by dengue virus infection that transmitted by Aedes Aegypti mosquite. The world population at risk of dengue disease is estimated to reach 2.5-3 billion, especially those living in urban areas in tropical and subtropical countries. It is also estimated there are 50 million dengue infections that occur each year ${ }^{(1)}$.

Incidence rate of Dengue Hemorrhagic Fever (DHF) in Indonesia in 2014 was lower than the previous year. The incidence rate in 2011 was 29.93 per 100,000 population, in 2012 is 36.8 per 100,000 population, in 2013 was 45.85 per 100,000 population, and in 2014 was 29.21 per 100,000 population. Although the incidence rate lower than national standards (50 per 100.000 population), but it necesarry to prevention DHF diseases ${ }^{(2)}$.

East Java is one of the provinces with the highest DHF case in Indonesia. The incidence rate of DHF in East Java in the last 5 years is fluactive. Incidence rate of DHF in East Java continue to increase from 2010 until $2014^{(3)}$. The highest incidence rate of DHF occurred in 2015 with 52.72 per 100,000 population. It showed that incidence rate of DHF in 2014 is higher than national standards. Incidence rate of DHF can be seen in figure 1.

The emergence of these problems will not actually happen if the implementation of epidemiological surveillance in the region goes well. Surveillance is not only used to count the number of cases, but also as a tool to describe the population at risk, eradicate the disease, and prevent the spread of disease. Trough the availability of data or the valid and accurate information will certainly produce the control programs or disease eradication that more effective and efficient ${ }^{(4)}$. 


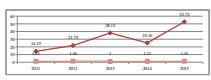

Figure 1. Incidence Rate (IR) and Case Fatality Rate (CFR) Dengue Hemorrhagic Fever in East Java Province 2011-2015

The purpose of the surveillance system are the availability of epidemiological data and information as the basis of health management for decision making in the planning, implementation, monitoring, evaluation of health programs and awareness raising as well as the rapid and precise response of the national, provincial and district/city ${ }^{(5)}$. The surveillance system should be periodically evaluated, and its evaluation should result in recommendations for improvement of quality, efficiency and usefulness ${ }^{(6)}$.

Therefore, an evaluation or assessment of P2DBD surveillance at the Pauruan District Health Office is based on surveillance attributes that include simplicity, flexibility, data quality, acceptability, sensitivity, positive predictive value, representation, timeliness and stability. Therefore, it was required an evaluation of the implementation of P2DBD surveillance in health office of Pasuruan District based on surveillance attribute that include simplicity, flexibility, data quality, acceptability, sensitivity, positive predictive value, representation, timeliness and stability. The purpose of this study was to describe the problem of DHF surveillance based on attributes as well as provide an alternative solution.

\section{METHODS}

This research used a descriptive study with evaluation study design. The subjects of the study were DHF Program officers of Health Office and 16 Community Health Center surveillance officers in Pasuruan District. This research was conducted in the Health Office of Pasuruan This research was conducted in the Health Office of Pasuruan District working area, East Java Province in May to June 2016. Implementation of epidemiological surveillance included surveillance attributes consisted of simplicity, flexibility, acceptability, sensitivity, positive predictive value, representation, timeliness, data quality and stability. The data collected was formed in primary and secondary data. Primary data was obtained by interviewing DHF officers. While the secondary data was obtained by documentary study obtained from the Health Office and Community Health Centers in Pasuruan District. Interviews were provided to surveillance officers to know the implementation of DHF case surveillance while document studies are applied to find out the various forms used to conduct case surveillance. The instruments used for collecting data in this study were interview guides, document study sheets and tape recorder. Data was analyzed descriptively by describing a real situation of the research then evaluated by using attribute of surveillance.

\section{Simplicity}

\section{RESULTS}

Table 1. The evaluation result of simplicity components on DHF surveillance in Health Office of Pasuruan District

\begin{tabular}{|c|c|c|c|c|}
\hline Number & Criteria & Results & Percentage & Classification \\
\hline 1 & $\begin{array}{l}\text { Collecting and } \\
\text { reporting the data }\end{array}$ & $\begin{array}{l}\text { Ease of collecting and } \\
\text { reporting data }\end{array}$ & 100 & Simple \\
\hline 2 & Availability of funds & $\begin{array}{l}\text { Funds available to } \\
\text { surveillance the case of DHF }\end{array}$ & 100 & Simple \\
\hline 3 & $\begin{array}{l}\text { Processing and data } \\
\text { analysis }\end{array}$ & $\begin{array}{l}\text { processing and analysis of } \\
\text { data is easy to do. }\end{array}$ & 100 & Simple \\
\hline 4 & $\begin{array}{l}\text { Dissemination of } \\
\text { information }\end{array}$ & $\begin{array}{l}\text { Dissemination of information } \\
\text { is usually done by } 3 \text { month }\end{array}$ & 62.5 & Not Simple \\
\hline
\end{tabular}


The simplicity of a surveillance system includes simplicity in terms of structure and ease of flow of reporting and operation. The surveillance system should be designed as simple as possible, but still achieving the desired goals. The evaluation results of simplicity components on DHF surveillance in Health Office of Pasuruan District can be seen in Table 1.

\section{Flexibility}

A flexible surveillance system can adapt to changes in required information or implementation situations without a meaningful increase in the need for cost, labor and time. Flexible systems can accept, for example, newly identified disease and health problems, change of case definitions, and variations from reporting sources. The evaluation results of flexibility components on DHF surveillance in Health Office of Pasuruan District can be seen in Table 2 .

Table 2. The evaluation result of flexibility components on DHF surveillance in Health Office of Pasuruan District

\begin{tabular}{cllcc}
\hline Number & \multicolumn{1}{c}{ Criteria } & \multicolumn{1}{c}{ Results } & Percentage & Classification \\
\hline 1 & $\begin{array}{l}\text { Implementation of } \\
\text { reporting data use } \\
\text { goggle drive }\end{array}$ & $\begin{array}{l}\text { There was no additional cost, } \\
\text { power and time }\end{array}$ & 100 & Flexible \\
\hline
\end{tabular}

AcceptabilityAcceptability describes the willingness of a person or organization to participate in conducting surveillance systems. The evaluation results of acceptability components on DHF surveillance in Health Office of Pasuruan District can be seen in Table 3.

Table 3. The evaluation result of acceptability components on DHF surveillance in Health Office of Pasuruan District

\begin{tabular}{cllcc}
\hline Number & \multicolumn{1}{c}{ Criteria } & Results & Percentage & Classification \\
\hline 1 & Participation in data collection & Willing & 92 & Acceptable \\
2 & Participate in data reporting & Willing & 100 & Acceptable \\
3 & Participate in data analyze & Unwilling & 18.75 & Not Acceptable \\
4 & Participate in information & Feedback was done & 62.5 & Not Acceptable \\
& dissemination and feedback & only 3 months & & \\
\hline
\end{tabular}

\section{Sensitivity}

Sensitivity is the ability of the system to be able to capture accurate information data. The sensitivity in DHF surveillance aims to detect the proportion of cases and monitor change of case at any time, especially in the quarter. Indicators used in sensitivity assessment are seen from timely data processing. The evaluation results of sensitivity components on DHF surveillance in Health Office of Pasuruan District can be seen in Table 4.

Table 4. The evaluation result of sensitivity components on DHF surveillance in Health Office of Pasuruan District

\begin{tabular}{cllcc}
\hline Number & \multicolumn{1}{c}{ Criteria } & \multicolumn{1}{c}{ Results } & Percentage & Classification \\
\hline 1 & $\begin{array}{l}\text { Detected outbreak and } \\
\text { change of case }\end{array}$ & $\begin{array}{l}\text { Surveillance can detected the } \\
\text { outbreak of DHF and can } \\
\text { monitoring the change of case in } \\
\text { Pasuruan District }\end{array}$ & 82.5 & Sensitive \\
\hline
\end{tabular}

\section{Representativeness}

Representative means it can accurately describe various events or health events at all times including their dissemination in the population by time and place. Data processing by Pasuruan District health office were representative because those has been processed based on the place and time. The evaluation results of representativeness components on DHF surveillance in Health Office of Pasuruan District can be seen in Table 5.

Table 5. The evaluation result of representativeness components on DHF surveillance in Health Office of Pasuruan District 


\begin{tabular}{cllr}
\hline Number & \multicolumn{1}{c}{ Criteria } & \multicolumn{1}{c}{ Results } & Classification \\
\hline 1 & $\begin{array}{l}\text { Describing the case } \\
\text { population by time } \\
\text { Describing the case } \\
\text { population by place }\end{array}$ & $\begin{array}{l}\text { Surveillance system can't describe } \\
\text { various case by the time } \\
\text { Surveillance system can't describe } \\
\text { various case by the place }\end{array}$ & Not Representative \\
& Not Representative \\
\hline
\end{tabular}

\section{Timeliness}

Timeliness means the rate of speed or delay between the steps that must be taken in a surveillance system. In addition, the time required to determine trends (trend), outbreak, or assess the influence of efforts to overcome. The evaluation results of Timeliness components on DHF surveillance in Pasuruan District health office can be seen in Table 6.

Table 6. The evaluation result of timeliness components on DHF surveillance in Health Office of Pasuruan District

\begin{tabular}{cllcr}
\hline Number & \multicolumn{1}{c}{ Criteria } & \multicolumn{1}{c}{ Results } & Percentage & Classification \\
\hline 1 & Case reporting & $\begin{array}{l}\text { Case reporting always done in less for } \\
\text { 24 hours }\end{array}$ & 94 & On time \\
2 & $\begin{array}{l}\text { Information } \\
\text { dissemination } \\
\text { and feedback }\end{array}$ & $\begin{array}{l}\text { Information dissemination is done } \\
\text { once every 3 months and feedback } \\
\text { monitoring and evaluation is done } \\
\text { only 2 times a years }\end{array}$ & 62.5 & Not on time \\
\hline
\end{tabular}

\section{Data Quality}

Data quality is an important part of representation. Data quality describes the completeness and validity of the data recorded in the public health system. Data quality can be seen from the "unknown" or "empty" percentage of items on the surveillance form. High quality data will have a low percentage of such responses The quality of data of DHF surveillance in Pasuruan District health office was high because of the absence of data gaps found. The data that reporting always complete with laboratory assessment.

\section{Stability}

Stability refers to the ability to collect, manage, and provide data without error and the ability of the system to operate when needed. The evaluation results of stability components on DHF surveillance in Health Office of Pasuruan District can be seen in Table 7.

Table 7. The evaluation results of stability components on DHF surveillance in Health Office of Pasuruan District

\begin{tabular}{ccccc}
\hline Number & Criteria & \multicolumn{1}{c}{ Results } & Percentage & Classification \\
\hline 1 & $\begin{array}{l}\text { Manage and } \\
\text { provide data }\end{array}$ & $\begin{array}{l}\text { Respondent not manage and provide data } \\
\text { in every years. They save data on } \\
\text { computer but some data is lost. }\end{array}$ & 42.5 & Unstable \\
\hline
\end{tabular}

\section{DISCUSSION}

The simplicity of a surveillance system includes simplicity in terms of structure and ease of flow of reporting and operation. The surveillance system should be designed as simple as possible, but still achieving the desired goals ${ }^{(7)}$. The implementation of DHF surveillance in Health Office of Pasuruan District was simple because ease to collecting and reporting and analyze data. Funds is available when they needs. But there are not ease to dissemination of information because still done on 3 months. A flexible surveillance system can adapt to changes in required information or implementation situations without a meaningful increase in the need for cost, labor and time. According CDC (2001) Flexible systems can accept, for example, newly identified disease and health problems, change of case definitions, and variations from reporting sources. Implementation of DHF surveillance is flexible because there are $\mathrm{n}$ any additional cost and not need training when reporting data change from email to google drive. Acceptability describes the willingness of a person or organization to participate in conducting surveillance systems. Surveillance system in Pasuruan District is acceptable because respondent participate in 
collecting, reporting, and analyze the data. But there are not acceptable in dissemination and feedback of information because feedback only given on 3 months.

Sensitivity is the ability of the system to be able to capture accurate information data. The sensitivity in DHF surveillance aims to detect the proportion of cases and monitor change of case at any time, especially in the quarter. Indicators used in sensitivity assessment are seen from timely data processing. Sensitivity measurements require the validity of the data that has been collected ${ }^{(8)}$. According to Nelson and Sifakis (2007), a well sensitive surveillance system is essential to monitor disease trends. DHF surveillance is sensitive because surveillance can detected the outbreak and monitoring the change of case in Pasuruan District

According to Nelson and Sifakis (2007), presentation of endemic infectious disease data is essential for assessing the progress or decline of health status in a community. If surveillance reports are not representative, they can affect disease prevention programs. DHF surveillance in Pasuruan District is not representative because can't describe population based on time and place in village level. Timeliness means the rate of speed or delay between the steps that must be taken in a surveillance system. In addition, the time required to determine trends (trend), outbreak, or assess the influence of efforts to overcome ${ }^{1}$. Based on the indicators assessed, the timeliness in the surveillance system was still not accurate in feedback because feedback given every 3 months.

Data quality is an important part of representation. Data quality describes the completeness and validity of the data recorded in the public health system. Data quality can be seen from the "unknown" or "empty" percentage of items on the surveillance form. High quality data will have a low percentage of such responses. The quality of data of DHF surveillance in Pasuruan District health office is high because of the absence of data gaps found. The data that reporting always complete with laboratory assessment. Stability refers to the ability to collect, manage, and provide data without error and the ability of the system to operate when needed. Data is unstable because there are any respondent that loss of data and only have data only in 1-5 years.

\section{CONCLUSION}

The problems is not simple in feedback, not acceptable in feedback, and not on time in feedback because the feedback only give every 3 months. Data is not representative because data can't describe population based on time and place. Data is unstable because there are any respondent that loss of data and only have data only in 1-5 years. Providing personal computers for program officers is needed to keep the data from lost and always available. Motivate the Public Health Centers to form an independent jumantik cadre with funding sources from Public Health Centers or sub district for optimal PSN and data reports.

\section{REFERENCES}

1. World Health Organization. Dengue haemorrhagic fever. Geneva: WHO; 1995.

2. Kemenkes RI. Eradication of Dengue Hemorrhagic Fever (Eradikasi Demam Berdarah). Jakarta; Kemenkes RI; 2014

3. Dinkes Provinsi Jawa Timur. Health Profile of East Java 2012 (Profil Kesehatan Provinsi .Jawa Timur 2012). Surabaya; Dinkes Provinsi Jawa Timur; 2013.

4. Nelson KE, Sifakis F. "Chapter 4. Surveillance," in Infectious Disease Epidemiology: Theory and Practice. Sudbury, Mass, USA: Jones \& Bartlett Learning; 2007.

5. Kemenkes RI. Minister of Health of the Republic of Indonesia Decree No.1116/Menkes/SK/ VIII/2003 about Guidelines of the Implementation of Health Epidemiology Surveillance System (Peraturan Menteri Kesehatan RI No. 1116/Menkes/SK/VIII/2003 Tentang Petunjuk Penerapan Sistem Surveilans Epidemiologi Kesehatan). Jakarta: Kemenkes RI; 2003.

6. CDC. Updated Guidelines For Evaluating Public Health Surveillance Systems. MMWR2001/50 (RR13); 2001.

7. Murti B. The Principle and Method of Epidemiology (Metode dan Prinsip Epidemiology). $3^{\text {rd }}$ Ed. Yogyakarta; Gadjah Mada University Press; 2013.

8. Romaguera RA, German RR, Klaucke DN. Evaluating Public Health Surveillance dalam Teutsch, SM. \& Churchill, R. E.(eds.) 2000. Principles and Practice of Public Health Surveillance. New York: Oxford University Press; 2000. 